\title{
New Feasibility Approach with Conjoint Analysis for Urban Rail Transit Investments: A Case Study of Rize City
}

\author{
Hatice Gül Önder ${ }^{1}$ \\ ORCID: 0000-0002-4794-6923
}

\author{
Hayri Ulvi ${ }^{2}$ \\ ORCID: 0000-0003-2988-6215
}

\author{
Furkan Akdemir ${ }^{3}$ \\ ORCID: 0000-0003-0964-338X
}

\begin{abstract}
Urban rail investments are known to be one of the most popular solutions used by modern societies in terms of transportation needs and social sustainability. Urban rail systems are costly systems that require more resources. Therefore, investment decisions are taken with feasibility studies. As the feasibility studies in the present day predominantly evaluate the economic aspects of the investments. This attitude delays new investment processes that prevent urban development, so a feasibility approach is needed to fully evaluate the benefit potential of cities. In this study, primarily, feasibility frameworks and investment criteria of public transport systems have been explained. A new feasibility approach which is included using Conjoint Analysis has been developed that can evaluate different benefits of urban transportation investments. The feasibility of the different public transport scenarios produced within the scope of the transportation plan of Rize has evaluated by using the proposed feasibility approach. In a medium-sized city, criteria importance has determined for the return on investment $22 \%$, journey time $32 \%$, comfort $11 \%$, pollution $19 \%$, rent increase $4 \%$, spatial consumption $12 \%$. Among the criteria evaluated within the framework of the new feasibility method, it has been determined that the rapid bus line is more feasible investment alternative.
\end{abstract}

Keywords: Conjoint analysis, Feasibility studies, Public transportation, Rize.

\footnotetext{
${ }^{1}$ Instructor Dr., Ankara Hacı Bayram Veli University, E-mail: gul.onder@hbv.edu.tr

${ }^{2}$ Assoc. Prof., Gazi University, E-mail: hayriulvi@gazi.edu.tr

${ }^{3}$ City Planner, Ankara Metropolitan Municipality, E-mail: akdemirfurkan10@gmail.com

idealkent @ Kent Araştırmaları Dergisi (Journal of Urban Studies)

http://idealkentdergisi.com

Geliş Tarihi Received Date: 17.07.2020 Kabul Tarihi Accepted Date: 15.04.2021
} 


\section{Kentsel Raylı Sistem Yatırımlarında Konjoint Analizi İle Yeni Bir Fizibilite Yaklaşımı Önerisi: Rize Örneği}

\author{
Hatice Gül Önder ${ }^{4}$ \\ ORCID: 0000-0002-4794-6923
}

\author{
Hayri Ulvi ${ }^{5}$ \\ ORCID: 0000-0003-2988-6215
}

\author{
Furkan Akdemir ${ }^{6}$ \\ ORCID: 0000-0003-0964-338X
}

Öz

Kentsel raylı sistem yatırımlarının, ulaşım ihtiyaçlarının karşılanması ve sosyal sürdürülebilirlik açısından modern toplumlar tarafindan kullanılan en popüler çözümlerden biri olduğu bilinmektedir. Kentsel rayl sistemler fazla kaynak gerektiren maliyetli sistemlerdir. Bu nedenle yatırım kararları, fizibilite çalı̧̧malarıla alınmaktadır. Günümüzde fizibilite çalışmaları ağırlikl olarak yatırmların ekonomik yönlerini değerlendirirken, sosyal ve çevresel faydalar göz ardı edilmektedir. Söz konusu tutum yeni yatırım süreçlerini geciktirmekte, kentsel gelişimin önüne geçmekte, dolayısıyla kentlerin fayda potansiyelini tam anlamı ile değerlendirecek bir fizibilite yaklaşımına ihtiyaç duyulmaktadır. Bu çalışmada öncelikle kentsel raylı sistemler başta olmak üzere, toplu taşıma sistemlerinin literatürde yer alan fizibilite çerçeveleri ve yattrım ölçütleri açıklanmaktadır. Çalışmada Konjoint Analizi kullanılarak ve kent içi ulaşım yatırmmlarını farkl ekonomik, sosyal ve çevresel faydaları değerlendirilerek, farklı bir fizibilite yaklaşımı geliştirilmiştir. Geliş̧irilen fizibilite yaklaşımı ile Rize kenti ulaşım ana planı verilerinden yararlanılarak, plan kapsamında üretilen farklı toplu taşıma senaryolarının yatırım açısindan yapılabilirlikleri incelenmiştir. Çalı̧mada orta ölçekli bir kentte yatırım yapmak için, yatırım geri dönüş süresinin \%22, yolculuk süresinin \%32, konforun \%11, emisyon-çevresel kirliliğin \%19, rant artışının \%4, mekansal tüketimin \%12 önem düzeyinde olduğu tespit edilmiştir. Geliştirilen bu yeni fizibilite yöntemiyle değerlendirilen ölçütler arasında hızl otobüs hattının daha yapılabilir bir yatırm alternatifi olduğu tespit edilmişstir.

Anahtar Kelimeler: Konjoint analizi, fizibilite çalışması, toplu taşıma, Rize

\footnotetext{
${ }^{4}$ Dr. Öğr. Görevlisi, Ankara Hacı Bayram Veli Üniversitesi, E-mail: gul.onder@hbv.edu.tr

${ }^{5}$ Doç. Dr., Gazi Üniversitesi, E-mail: hayriulvi@gazi.edu.tr

${ }^{6}$ Yüksek Şehir Plancısı, Ankara Büyükşehir Belediyesi, E-mail: akdemirfurkan10@gmail.com

idealkent @ C Kent Araştırmaları Dergisi (Journal of Urban Studies)

http://idealkentdergisi.com

Geliş Tarihi Received Date: 17.07.2020 Kabul Tarihi Accepted Date: 15.04.2021
} 


\section{Introduction}

Today's cities are rapidly developing due to several ever-increasing social and environmental conditions. In this respect, transportation, which is among the factors impacting urban dynamics, has a key role as the most fundamental urban component enabling mobility of persons and goods. Transportation in urban areas is carried out through private vehicles and means of public transportation. However, in densely populated urban areas there are various alternative types of transportation modes for individuals to go from one place to another. These types of transportation are continuously evolving also as a result of technological advances. Hence, urban transportation is carried out for different motives of trip through suitable types and sizes of vehicles in accordance with such motives using the necessary infrastructure and superstructure elements.

While travelling in private vehicles, the destination is determined based on individual demand; however, while travelling through means of public transportation, what determines the destination is the transportation demands of individuals who happen to be at the same point at the same time and who want to travel to similar destinations or to destinations close to each other. That turns the issue of public transportation into a concept of service for local administrations (Dimitrou and Sartzetaki, 2017). Private vehicle uses and public transportation routes and systems are shaped according to all kinds of transportation demands in the city. In cities which develop through transportation, the biggest share is constituted by public transportation systems (Erdoğan, 2016). Although the issue of investments in the physical environment is directly related to economy, public transportation systems in particular are affected by many economic, social, and environmental parameters.

As a result of such transportation investments, accessibility in a city changes, which in turn impacts land and property market and which eventually results in problems with development and rent. It can be concluded from such a fact that the economic, social, and environmental impacts of transportation investments also affect one another (Banister and Thurstain- Goodwin, 2011). This situation shows that investments in developed countries are generally made on and channeled into transportation sector considering the economic, social, and environmental impacts of such investments. The European Union supports the establishment of high-quality transportation systems for its citizens in the light of the basic principles set for transportation. Moreover, 
European economy spends 1\% of its Gross Domestic Product annually to produce solutions for such issues (Russo and Comi, 2012).

Developed countries prefer rail systems to solve urban transportation problems using technological advancements to their advantage. In many metropolitan cities in the world, rail systems are among the ideal solutions for urban administrations when there is need for high-capacity passenger transportation. Even though it seems to be an important issue that urban rail systems have multiple benefits, high costs depending on technological possibilities make it necessary for administrations to make some serious decisions about the investments on such systems (Withanaarachchi \& Setunge, 2014).

Local administrations in modern cities have to consider various means of transportation in order to conserve their limited resources. In this respect, resources should be used responsibly and wisely regarding that rail transportation systems require high amounts of investment costs, and many countries are looking for ways to prevent waste of resources (Bilgiç, 2002, 6). One of those ways is to evaluate the planned investments based on different criteria and scales. The need of transportation, which is shaped according to transportation demands, is one of the most fundamental driving forces of new investments. It is seen that economic criteria are more effective in decisions about planned investments due to high costs, and potential investments are put into practice after a consideration of benefits and costs (Gündüz et al., 2011). In other words, investments in rail transportation systems are evaluated within the scope of feasibility studies. To put it briefly, feasibility studies are analyses of projected investments in terms of applicability, and they represent an interpretation of the realities emerging as a result of the analyses.

The concept of conventional feasibility develops on an axis where economic variables are predominant. Within the scope of the present study, a new feasibility model addressing today's conditions is compared to a conventional feasibility model, considering not only economic conditions but also the requirements of today's urban rail transportation systems and the physical, social, and environmental criteria. Thus, possible new investment decision criteria for urban rail systems are presented using a conjoint analysis.

In many large-medium-small-scale cities in Turkey, various transportation types and systems are used depending on the macroform, topography, natural features and typology of cities. In Turkey, OECD and EU city typologies generally depends on criterias related with demographic contents such as population, besides size of area, accessibility and land use types are also effective to classificate of city size (Gökyurt et al., 2015). 
In most of the cities there are various means of transportation such as private vehicles, buses, minibuses, shuttle, taxis, bicycles, and motorbikes, whereas in Istanbul the first means of transportation that spring to mind are funicular railways, metrobuses, and ferries. Such means of transportation are preferred according to the transportation demands and geography of the city. In cities such as Samsun, Ordu, and Giresun, there are also cable cars, which are used both for transportation and touristic purposes. In cities such as Ankara, Kayseri, Konya, Antalya, and Eskişehir trams are used, and in some other cities such as İzmir and İstanbul metro and suburban trains are used as means of transportation.

Considering that İstanbul is a metropolitan city which facilitates the integration among different types of transportation through air and sea transportation, there are also alternative, but relatively more expensive, means of transportation for those who would like to travel faster such as sea-taxis and air-taxis. The investments on transportation systems require very different spatial characteristics and physical environment just like the above-mentioned types of transportation, and very high costs. The investment cost of private cars is 16 times higher than that of buses, and 4 times higher than that of metro. However, on a single trip a private car carries 5 persons, whereas a bus carries 70 and the metro carries approximately 500 persons; a private car contributes 125 times more to air pollution than a bus. It is possible through investments on public transportation systems to ensure cash return in a shorter period of time and with less environmental damage (Kellog and Pettigrew, 2013, p.45).

In order to use national resources productively and to develop the economy of the country in the most effective way possible, infrastructure investments should be made considering the priorities of transportation sector in Turkey. In cities, commuting trips to or from different locations such as homework-shopping centers-school-entertainment centers is done via all types of transportation and systems. Therefore, it is important that transportation investments and land-use decisions be made and put into practice together. Transportation systems that connect residential areas and work areas, especially those which provide scheduled transportation such as the metro, tram, and metrobus, reduce the costs of time spent for transportation. Spending shorter time for commuting and knowing how long the commute takes will increase the confidence in public transportation, helping city dwellers about quality time management. In areas where transportation opportunities are facilitated, real estate prices will go up and so it is ensured that savings to be 
made from transportation costs are used to create more valuable areas. Thus, there will be a fast return of investments on public transportation for local administrations.

In Turkey, several principles and priorities about transportation investments and the development of transportation systems have been determined within the scope of country's vision and development programs. Within the scope of the Regional Development Vision, Objectives and Strategies, in the articles 365, 414, and 632, issues such as increasing the number of public transportation systems which will integrate the highway-sea-railway systems in urban transportation, increasing accessibility, and prioritizing environmental awareness have been touched upon (Anonymous, 2013a). Article 975 of the Tenth Development Plan prepared for the years 2014-2018 by the Turkish Ministry of Development laid emphasis on strengthening intersystem harmonization and integration based on transportation plans that are in line with spatial planning and development objectives in urban transportation, developing and transforming the infrastructure in a public-transport intensive way, and promoting environmentally sensitive, smart, productive, and cost effective Practices (Anonymous, 2013b).

In Article 987, it was stated that information technologies and smart transportation systems would be utilized in urban transportation and public transportation services. According to Article 985, in urban public transportation, systems such as buses and metrobuses are to be preferred considering the developments in transportation demands and, in the case that such systems fail to be sufficient, rail systems are to be preferred as alternative systems (Anonymous, 2013b). Regulation No 26901 of 9 June 2008 on Principles and Procedures for Increasing Energy Productivity in Transportation (Anonymous, 2008b), Section 5 of Article 10 on investments in public transportation systems emphasizes the place and importance of rail systems in ensuring energy productivity in urban transportation with the statement, in urban transport planning, rail system investments shall be increased in order to encourage public transport. As far as transportation vision and legislative background in Turkey is concerned, it can be seen that there is an emphasis on a community-minded approach which is supported by smart transportation systems, and which encourages the designation of a public transportation system prioritizing environment-friendly transportation. Within this framework, it is of importance that decisions about public transportation be evaluated together by both economic, and environmental and social criteria. 
Transportation investments have a nature that requires high costs but can pay off such costs in a short period of time when appropriate infrastructure and usage level are provided. When making decisions about public transportation in a city, by tradition there are certain criteria that should be considered; these are the size of the city and macroform, selection of appropriate transportation technologies according to transportation demands, costs, and potential environmental impacts of the selected public transportation type (Kılınçarslan, 2012,80). Macroform can be considered as current border of growing residental areas, infrastructu re etc. land use type and its consuming-transforming effects on natural environment (Görer Tamer et al., 2007).

When examined in terms of the size of the city macroform, large urban areas and the need for transportation to distant locations in metropolitan cities are indicators that investments in rail systems are more feasible. Rail systems not only are preferable regarding the macroform of the city and but also can shape the macroform of the city. As a requirement of multiple travel demands in urban transportation, the operation of bus lines that will serve to support rail system lines fosters the underground rail systems which allows for rapid access.

Turkish Ministry of Transportation, General Directorate of Railways, Harbors, and Airports set as a criterion that the population of a city should be at least 1 million for rail system investments to be made; however, it was later determined that this criterion is not that applicable considering the applications in cities worldwide. It was seen that in rail system investments, the population density of persons who are going to travel is more effective than the size of the population (Kılınçarslan, 2012). In a study conducted by Öğüt and Evren (2006), the correlation between the length of rail systems and city population was analyzed and no statistically significant correlation was found between the two.

When selecting the appropriate transportation technology according to travel demands, investments should be made considering that each means of transportation has its own passenger transportation capacity. During the 11th Transportation Council Meeting and Article 985 of the 10th Development Plan (Anonymous, 2013b), the criteria regarding the development of transportation in Turkey were tried to be determined and accordingly it was determined that the decisions about public transportation investments in our country are to be made in line with the statement, It is required that the planning should be made in the corridors that are anticipated to meet the condition of peak hour one way travel demands for the expected year of operation 
for rail systems; for tram systems, a minimum number of 7,000 passengers/hour; for light rail systems, a minimum number of 10,000 passengers/hour; and for metro systems, a minimum number of 15,000 passengers/hour. Nevertheless, the satisfiability of those conditions should be questioned considering transportation systems require certain processes of acquaintance- adaptation-routine. What is signified by the cost criteria is the evaluation of the land costs, construction costs, vehicle costs, operating costs, and maintenance costs of a public transportation investment together. When a type of public transport requires its own infrastructure, the construction, maintenance, and operating costs are much higher. Transportation types such as buses and minibuses require less costs for land, construction, and maintenance since they can be operated more flexibly.

In this study, Rize city has been selected as a study area. Rize city is located in the northeastern part of Turkey. The city has a high and slopy physical structure. Due to physical thresholds, suitable settlements in this city are low. Transportation services are going from the city center through hilly terrain with low population density. Transportation services are providing from the city center toward hilly terrain settlements that have low population density (Deniz et al.,2020).

The natural beauty of the city of Rize is frequently emphasized in the studies. Therefore, it is emphasized that when projects affect the public spaces of the city, the necessary importance should be given in terms of natural wealth, population, and land use (Alkan and Yazıcıoğlu, 2017). It is understanding from that the city of Rize is a suitable study area to evaluate a method that addresses different aspects in terms of analyzing multiple alternatives within the scope of taking an urban investment decision. In an assessment made especially related to the transportation structure of the city, the transportation network of the city of Rize has evaluated to be insufficient. This emphasis shows that the city opens to new investments. In the same study, the urban population rate of Rize city in 2012 is stated as 64\% (Sümer, 2014). Rize transportation master plan one of the studies that bring up different public transportation investments, including the urban rail system. According to the transportation master plan data which has made in 2017, the city, which has a total size of $3.835 \mathrm{~km}^{2}$, has a population of 331.041 in 2017 (KUTEM, 2018).

As stated before, legal texts give priority to economic criteria in urban public transport investments. While large-scale cities are advantageous in terms of passenger and trip potential and economic thresholds, small and mediumsized cities are disadvantageous in this aspect. An approach based solely on 
providing economic thresholds prevents the social and environmental benefits to be gained in developing cities, thus it also has an obstacle role in the development of medium and small-scale cities. The effect of different criteria in making investment decisions will be better understood when examined in small and medium-sized cities.

The aim of the study in this perspective is to reveal the importance of social and environmental criteria against economic criteria in making an investment decision that will affect urban development over a medium-sized city.

In the literature, large-scale cities defined as grow uncontrolled and rapidly, where a lot of money is spent on transportation, $40-50 \%$ of their journeys are home-business trips. Other hands, mixed economic function land use, unspoiled and lower level home-business travel with sustainability potential cities are defined as medium scale. The city of Rize has a $28 \%$ home-business travel rate. Rize was chosen as the study area as a medium-sized city in terms of its stated characteristics such as population, sustainability, environment, etc. (Akdemir et al., 2018)

\section{Methodological Explanations}

Urban rail transportation systems are costlier compared to other means of transportation due to system requirements. Those requirements vary depending on the technological structures of the systems. If there is a bus system within the scope of the public transportation system, it means bus fleets are included and if there is a rail system, then wagons, rails, and electrical systems are included. Since the day they started to become widespread, urban rail systems have been evaluated from different perspectives by the authorities as part of investment programs. The general perspective regarding the evaluation of urban public transportation investments varies in the analyzed examples in Turkey and in the world. The feasibility study of Metro 4 in Athens, Greece used a criterion classification. It was stated in the study that a basic contents table for feasibility was formed based on an analysis of examples from 7 different countries. Table 2 presents the concepts related to the project.

In the study, although investment decisions were made based on values such as the net present value, internal rate of return, and benefit-cost ratio, it was emphasized that one of the most important components impacting the decision-making process was the fact that the number of private cars in traffic 
decreased as a result of effective investments. In this example it was frequently highlighted that social and environmental criteria are significant when making decisions about investments (Tsimplokoukou et al., 2012) Another example is about the selection of the rail system line to Bradley Airport in the United States of America. The project has been planned as a rail line to be operated between Bradley Airport and the residential areas close to the airport. As can be seen in Table 1, there are 4 transportation alternatives developed for the route between the airport and the residential areas within the scope of the project. The applicability of the project is determined through an analysis of the impact of route alternatives on the environment, and environment is used as a criterion. Table 1 shows the alternatives determined and the environmental impacts of those alternatives. It has been stated that the second scenario, Alternative 2, would have less of a negative impact on the environment and, therefore, it was preferred to other alternatives within the scope of the project. Regarding this project, it is seen that environmental criteria based on the potential impact analyses of investment scenarios have been more effective than economic criteria in the decision-making process (AECOM, 2016).

Table 1. Impact Analysis (AECOM, 2016)

\begin{tabular}{|c|c|c|c|c|}
\hline & Scenario 1 & Scenario 2 & Scenario 3 & Scenario 4 \\
\hline Wetland & $5,9 \mathrm{Ha}$ & 2,7 Ha & 9,1 Ha & $27,9 \mathrm{Ha}$ \\
\hline Flood Plain & $7,0 \mathrm{Ha}$ & $5,3 \mathrm{Ha}$ & $46,3 \mathrm{Ha}$ & $63,5 \mathrm{Ha}$ \\
\hline Open Areas & $12 ., 1 \mathrm{Ha}$ & $13,6 \mathrm{Ha}$ & $7,2 \mathrm{Ha}$ & $36,1 \mathrm{Ha}$ \\
\hline Critical habitat & - & - & - & $2,3 \mathrm{Ha}$ \\
\hline Rare Plant Areas & $123 \mathrm{Ha}$ & $92,5 \mathrm{Ha}$ & $210,6 \mathrm{Ha}$ & $245.6 \mathrm{Ha}$ \\
\hline Total Area & $148 \mathrm{Ha}$ & $114,1 \mathrm{Ha}$ & $273,2 \mathrm{Ha}$ & $375,4 \mathrm{Ha}$ \\
\hline Suggested Track Length & $6,2 \mathrm{mil}$ & $4,4 \mathrm{mil}$ & $4,1 \mathrm{mil}$ & $6,8 \mathrm{mil}$ \\
\hline Land use in the Route & $\begin{array}{l}\text { Industry, } \\
\text { house, } \\
\text { commercial }\end{array}$ & $\begin{array}{l}\text { Industry, } \\
\text { house, } \\
\text { commercial }\end{array}$ & $\begin{array}{l}\text { Industry, } \\
\text { house, } \\
\text { commercial }\end{array}$ & $\begin{array}{l}\text { Industry, } \\
\text { house, } \\
\text { commercial }\end{array}$ \\
\hline
\end{tabular}

Both studies show that while the general perception about the evaluation of investments in urban public transportation mostly focus on economic criteria, in some examples the social and economic benefits that the investments will generate are especially taken into consideration.

As far as the analyzed Turkish examples are concerned, there are differences in terms of the traditional perspective compared to cities in the world. One of those differences can be observed in the feasibility study of the present railway line in Diyarbakır province. In the study, the investments are evaluated based on the net present value and internal rate of return. It has been 
emphasized in the study that the investment is feasible due to the public benefit it will provide, although it is not feasible economically (Anonymous, 2011). Another example concerns the extension of Konya tram line; different alternative scenarios are developed for potential investments. Regarding the applicability of the scenarios, it is stated that all scenarios are feasible because net present value, internal rate of return, and benefit-cost ratio are all at the desired level; the main reason for that is stated to be the high rate of travel demand at the peak hour (Anonymous, 2008a). Yet another example is the prefeasibility analysis and preliminary projects of Sakarya transportation master plan and primary public transportation systems. What makes this study unique is that it aims to develop a new perspective on feasibility studies by including social and environmental criteria as well as economic criteria; in the study, social and environmental criteria are dealt with considering their economic aspects, which have been determined as vehicle operation and journey time costs, fuel consumption and emission unit consumption costs, car ownership costs, fuel consumption costs, emission costs, noise costs, accident costs, water pollution costs, and time-value costs. In the Sakarya study, it has been stated that the criterion by which the street tram proposal was determined to be feasible was the one-way peak hour travel demand in the section in the related year (Anonymus, 2013c).

The studies in Turkey show that the determining factor in urban rail system investments is the one-way peak hour number of passengers, or in other words, a travel demand of 7000 travels in the section within the scope of Article 985 of the 10th Development Plan. While in other examples in the world there seems to be an effort to consider economic criteria and social and environmental criteria as a whole, and even to see certain projects in practice before making evaluations, in Turkish examples it seems that economic criteria have the final say in investment decisions.

As far as the general perspective in the evaluation of investments on urban rail systems is concerned, we see that economy-based approaches are prioritized, while social and environmental approaches remain secondary. Although making evaluations based on economic criteria while making decisions about investments increases the economic efficiency, it, on the other hand, prevents the possible social and environmental benefits that can be generated. An alternative perspective could be, as in the example of Diyarbakır, that the public benefits of a given investment render it feasible.

Globally speaking, one of the most effective issues in determining the impact of infrastructure investments is the use of resources (Şahin, 2012). Use of 
resources for investments refers to in the economic sense the monetary expenses, in the social sense the steering of employment, and in the environmental sense the transformation of urban environmental structure. Regarding transportation, in order to carry out most of the investments must be present in land. Today, the urban planning discipline is commonly employed for such undertakings.

Transportation master plan is a planning instrument through which new proposals are generated for the land use access of city residents. In order to ensure interaction between land uses, there seems to be a search for new infrastructure and superstructure, sometimes out of necessity and sometimes as a design element. Transportation infrastructure, in particular, is reflected in the urban agenda as investments or investment programs, and the quality and quantity of the infrastructure vary according to the country, region, city, and neighborhood it will serve (Spiekermann \& Wegener, 2006). According to the current understanding, the positive and negative economic consequences of transportation investments, which are mostly evaluated through feasibility studies, determine whether the investments should be made, easin $\mathrm{g}$ the job of decision-makers (Bilgiç, 2002).

In the literature, conjoint analysis method is commonly preferred because it is an analysis that enables the quantitative and qualitative features of a service or product determined by the researchers to be measurable and comparable (Turanlı et al. 2013; Ben - Akiva et al., 2019).

Conjoint analysis mainly focuses on the preferences of people and tries to determine the details regarding potential preferability of the service. What is particularly aimed at in the present study is to bring together and rank different levels of certain variables of the service. Considering all of the above, in the present study ranking-based conjoint analysis, which is one of the conjoint method implementation techniques, is used (Cankurt et al. 2009; Aktaş et al. 2012). According to conjoint analysis, the procedures of the technique are as follows (Yavuz and Çemrek, 2013):

1. Determination of the attribute to be measured based on service

2. Conducting a level research of the attribute

3. Preparation of the choice cards for conjoint analysis

4. Classification of the cards into groups of participating experts

5. Analysis of the formation of preferences (SPSS can be used.)

The 1st and 2nd stages are important stages which determine the preference function to be selected for the study. Preference functions are vector, 
ideal point, and piecewise functions (Turanlı et al. 2013, 6). As mentioned in step 4 experts have chosen from public authorities such as decision maker urban planners of related ministry, professors from universities who has studies and experience about transportation and planning, related industrial cluster experts such as railway clusters. Experts of transport departments in municipalities. The reason behind that selective approach of experts that they are currently working in this kind of decision making process needing projects as decision makers.

The necessary information about the criteria and levels of criteria levels in conjoint analysis is obtained from studies conducted in the field of transportation and especially studies which used conjoint analysis to study transportation. The relevant criteria and levels of criteria are presented in Table 2.

Table 2. Criterias and Level of Criterias

\begin{tabular}{|c|c|c|c|}
\hline Criterion & Levels & Explanation & Literature Source \\
\hline \multirow{3}{*}{$\begin{array}{l}\text { Return on invest- } \\
\text { ment }\end{array}$} & 1 year & \multirow{3}{*}{$\begin{array}{l}\text { The length of self-amortization } \\
\text { time for any public transporta- } \\
\text { tion system investment in the } \\
\text { short-medium-long term. }\end{array}$} & \multirow{3}{*}{$\begin{array}{l}\text { Haghshenas and } \\
\text { Vaziri (2012) } \\
\text { Baştürk, G. (2014) }\end{array}$} \\
\hline & 5 years & & \\
\hline & 10 years & & \\
\hline \multirow[t]{3}{*}{ Journey Time } & $\begin{array}{l}\text { Shorter than the } \\
\text { current time }\end{array}$ & \multirow{3}{*}{$\begin{array}{l}\text { The change of increase or de- } \\
\text { crease in urban travel time } \\
\text { with any public transportation } \\
\text { system investment. }\end{array}$} & \multirow{3}{*}{$\begin{array}{l}\text { Newman, } \\
(2012) \text {. } \\
\text { Wardman, } \\
(2014)\end{array}$} \\
\hline & $\begin{array}{l}\text { The current time } \\
\text { does not change }\end{array}$ & & \\
\hline & $\begin{array}{l}\text { Longer than the } \\
\text { current time }\end{array}$ & & \\
\hline \multirow[t]{2}{*}{ Comfort } & Comfort-oriented & \multirow{2}{*}{$\begin{array}{l}\text { It signifies the comfort priority } \\
\text { in any public transportation } \\
\text { system investment }\end{array}$} & \multirow{2}{*}{$\begin{array}{l}\text { Zak, (2011) } \\
\text { Kim and Han, } \\
(2011)\end{array}$} \\
\hline & $\begin{array}{l}\text { Not comfort-ori- } \\
\text { ented }\end{array}$ & & \\
\hline \multirow[t]{2}{*}{ Emission } & $\begin{array}{l}\text { More than the cur- } \\
\text { rent one }\end{array}$ & \multirow{2}{*}{$\begin{array}{l}\text { It expresses the emission } \\
\text { change to occur after a public } \\
\text { transportation system invest- } \\
\text { ment. }\end{array}$} & \multirow{2}{*}{$\begin{array}{l}\text { Murteza, M. } \\
(2010), \\
\text { Haghshenas and } \\
\text { Vaziri (2012) }\end{array}$} \\
\hline & $\begin{array}{l}\text { Less than the cur- } \\
\text { rent one }\end{array}$ & & \\
\hline \multirow{3}{*}{$\begin{array}{l}\text { Spatial } \\
\text { Consumption }\end{array}$} & Small & \multirow{3}{*}{$\begin{array}{l}\text { The size of the area to be occu- } \\
\text { pied by the new investment. }\end{array}$} & \multirow[t]{3}{*}{ Şahin S. Z., (2012) } \\
\hline & Medium & & \\
\hline & High & & \\
\hline \multirow[t]{3}{*}{ Rent } & Low & \multirow{3}{*}{$\begin{array}{l}\text { The size of rent that any public } \\
\text { transportation system invest- } \\
\text { ment is likely to create in the } \\
\text { future. }\end{array}$} & \multirow[t]{3}{*}{ Kılıçaslan (2015) } \\
\hline & Medium & & \\
\hline & High & & \\
\hline \multirow{3}{*}{$\begin{array}{l}\text { Environmental } \\
\text { Pollution }\end{array}$} & Little & \multirow{3}{*}{$\begin{array}{l}\text { It signifies the level of environ- } \\
\text { mental pollution (noise, visual } \\
\text { pollution, etc.) that any public } \\
\text { transportation investment will } \\
\text { cause. }\end{array}$} & \multirow{3}{*}{$\begin{array}{l}\text { Murteza, M. } \\
\text { (2010), Van der } \\
\text { Loop ve De Jong, } \\
(1997)\end{array}$} \\
\hline & Medium & & \\
\hline & High & & \\
\hline
\end{tabular}




\section{Findings}

As a result of a detailed literature review on conjoint analysis, 7 criteria were determined for the investment attributes of public transportation services. There are 22 choice cards, which have been formed by combining different levels of these attributes. In order to have a choice-based ranking in conjoint analysis, it was required that the cards were ranked by expert participants based on the issues of transportation and transportation systems, data analysis, and criteria setting. Table 3 presents a randomly-selected example card which is to be used by experts during ranking. The ranking process from 1 to 22 is followed by the process of transferring the obtained ranking information to the computer. Doing conjoint analysis using SPSS 20.00 program promotes that healthier results are obtained for the study. In the so-called Syntax section of the SPSS 20.0 program, it is, first of all, necessary that definitions regarding variable levels and preferences be made. Therefore, for the criteria used in the study, the definitions are determined as follows: "linear more" for variables which are expected to have a linear increase with the increase in criterion level; "linear less" for variables which are expected to have a linear decrease, and "discrete" for variables which are classified as categorical.

Table 3. Criteria and Levels of Criteria of an Example Card (Combination)

\begin{tabular}{ll}
\hline Order of Preference & $\mathbf{X}$ \\
\hline Return on investment & 1 Year \\
\hline Journey Time & Shorter than the current time \\
\hline Comfort & Not comfort-oriented \\
\hline Emission & Less than the current one \\
\hline Spatial Consumption & Little \\
\hline Rent & Little \\
\hline Environmental Pollution & High \\
\hline Card No $X$ & \\
\hline
\end{tabular}

The coding used in Syntax section is as follows;

CONJOINT PLAN = 'D: $\backslash$ cardss.sav'

/DATA ='D: $\backslash$ Pref.sav'

$/ S U B J E C T=$ ID

/SEQUENCE=PREF1 TO PREF22

/FACTORS=investment (LINEAR LESS)

journey time (LINEAR LESS) comfort (LINEAR LESS) emission (LINEAR LESS) spatial_consumption (LINEAR LESS) rent (LINEAR MORE) environmental_pollution (LINEAR LESS)

$/ \mathrm{PLOT}=\mathrm{ALL}$

$/$ PRINT $=$ SIMULATION ALL . 
As a result of the analysis, the criteria that are considered by experts in public transportation investments and significance values are as in Table 4. It is seen that in the benefit levels of the criteria, negative benefit estimates, in addition to the rent criterion, are included. The negative values on the table signify that those levels are not noteworthy; when evaluated between different levels of the same criterion, the negative values show that one criterion is more preferred or less preferred than another one. In this regard, it can be seen that in the cards in which journey time show more negative values than in other cards, the return on investments has pushed the ranking preferences of experts towards the bottom of the list against the increase. Although in the case that the benefit estimation has a negative value, a linear decrease is expected as the criterion level increases, and a linear increase is expected as the criterion level decreases, the experts' decision could be contrary to expectations in practice.

Table 4. Significance Values

\begin{tabular}{|c|c|c|c|c|}
\hline & $\begin{array}{l}\text { Significance Val- } \\
\text { ues }(\%)\end{array}$ & Benefits & $\begin{array}{l}\text { Benefit Esti- } \\
\text { mation }\end{array}$ & $\begin{array}{l}\text { Std. Er- } \\
\text { ror }\end{array}$ \\
\hline \multirow{3}{*}{ Investment } & \multirow{3}{*}{22,503} & 1 Year & $-2,237$ & ,085 \\
\hline & & 5 Years & $-4,474$ & ,171 \\
\hline & & 10 Years & $-6,711$ & 256 \\
\hline \multirow{3}{*}{ Journey Time } & \multirow{3}{*}{32,079} & $\begin{array}{l}\text { Shorter than the current } \\
\text { time }\end{array}$ & $-3,490$ & ,092 \\
\hline & & $\begin{array}{l}\text { The current time does not } \\
\text { change }\end{array}$ & $-6,980$ & 184 \\
\hline & & $\begin{array}{l}\text { Longer than the current } \\
\text { time }\end{array}$ & $-10,471$ & ,275 \\
\hline \multirow{2}{*}{ Comfort } & \multirow{2}{*}{11,187} & Comfort-oriented & $-2,445$ & , 148 \\
\hline & & Not comfort-oriented & $-4,891$ & ,296 \\
\hline \multirow[b]{2}{*}{ Emission } & \multirow[b]{2}{*}{7,071} & Less than the current one & $-1,357$ & , 130 \\
\hline & & $\begin{array}{l}\text { More than the current } \\
\text { one }\end{array}$ & $-2,714$ & ,260 \\
\hline \multirow{3}{*}{$\begin{array}{l}\text { Spatial Consump- } \\
\text { tion }\end{array}$} & \multirow{3}{*}{12,612} & Little & $-1,369$ & 087 \\
\hline & & Moderate & $-2,738$ & , 175 \\
\hline & & High & $-4,107$ & ,262 \\
\hline \multirow{3}{*}{ Rent } & \multirow{3}{*}{4,053} & Low & ,042 & ,107 \\
\hline & & Moderate & ,085 & ,213 \\
\hline & & High & ,127 & ,320 \\
\hline \multirow{3}{*}{$\begin{array}{l}\text { Environmental } \\
\text { Pollution }\end{array}$} & \multirow{3}{*}{10,495} & Little & $-1,061$ & 089 \\
\hline & & Moderate & $-2,122$ & , 178 \\
\hline & & High & $-3,184$ & 267 \\
\hline Constant & & & 30,963 & ,537 \\
\hline
\end{tabular}


Since public transportation types are different from one another, their technical features and the benefits they are supposed to provide might differ. The benefit estimates presented in Table 4 apply to only certain types of transportation. The estimated benefit values obtained as a result of the conjoint analysis carried out by considering the opinions of the experts regarding medium-sized cities can be used for investment decision evaluations in the medium-sized Rize province in Turkey. In the present study, calculations have been made based on the benefit estimation values from the conjoint analysis and on the data from Rize transportation master plan (Anonymous, 2018).

As can be seen in the transportation master plan for Rize province, in order to solve transportation problems in the city and to improve the system in general, there are 3 different investment scenarios and 1 scenario projecting the improvement of the current situation; direct bus line, monorail, and tram, and the improvement of the current situation (Anonymous, 2018). In Table 5, the technical features of different scenarios based on 3 different investment propositions are presented.

Table 5. Criteria and Levels of Criteria An Example Card (Combination)

\begin{tabular}{|c|c|c|c|c|c|c|c|c|c|}
\hline \multirow[b]{2}{*}{ Years } & \multicolumn{3}{|c|}{ Rapıd Bus Line Scenario } & \multicolumn{3}{|c|}{ Monorail Scenarıo } & \multicolumn{3}{|c|}{ Tram Scenario } \\
\hline & 2022 & 2027 & 2032 & 2022 & 2027 & 2032 & 2022 & 2027 & 2032 \\
\hline $\begin{array}{l}\text { Speed } \\
(\mathrm{km} / \mathrm{h})\end{array}$ & 40 & 40 & 40 & 40 & 40 & 40 & 40 & 40 & 40 \\
\hline $\begin{array}{l}\text { Distance } \\
(\mathbf{k m})\end{array}$ & 17 & 17 & 17 & 11 & 11 & 11 & 10 & 10 & 10 \\
\hline Time (min) & 25.5 & 25.5 & 25.5 & 16.5 & 16.5 & 16.5 & 15 & 15 & 15 \\
\hline $\begin{array}{l}\text { Rotation } \\
\text { Time (min) }\end{array}$ & 51 & 51 & 51 & 33 & 33 & 33 & 30 & 30 & 30 \\
\hline $\begin{array}{l}\text { Number of } \\
\text { Rounds }\end{array}$ & 5 & 6 & 8 & 5 & 6 & 8 & 4 & 5 & 7 \\
\hline $\begin{array}{l}\text { Vehicle } \\
\text { Capacity } \\
\text { (persons) }\end{array}$ & 100 & 100 & 100 & 200 & 200 & 200 & 275 & 275 & 275 \\
\hline $\begin{array}{l}\text { Unit Capac- } \\
\text { ity }\end{array}$ & 100 & 100 & 100 & 200 & 200 & 200 & 275 & 275 & 275 \\
\hline $\begin{array}{l}\text { Number of } \\
\text { Units }\end{array}$ & 4 & 5 & 7 & 4 & 5 & 7 & 3 & 4 & 6 \\
\hline $\begin{array}{l}\text { Number of } \\
\text { Vehicles in } \\
\text { the Unit }\end{array}$ & 1 & 1 & 1 & 1 & 1 & 1 & 1 & 1 & 1 \\
\hline $\begin{array}{l}\text { Frequency } \\
\text { of Rounds } \\
\text { (min) }\end{array}$ & 11 & 8.7 & 6.2 & 7.3 & 5.8 & 4.1 & 7.9 & 6.2 & 4.15 \\
\hline $\begin{array}{l}\text { Total Capac- } \\
\text { ity }\end{array}$ & 463 & 586 & 822 & 904 & 1137 & 1609 & 1044 & 1330 & 1988 \\
\hline
\end{tabular}


Table 6 presents the features of scenarios within the scope of Rize transportation master plan in details. In the table, energy consumption, air pollution, noise, access time, travel costs, and investment costs of each investment proposal for each scenario are given (KUTEM, 2018).

Table 6. RUAP Scenario Detail Features (KUTEM, 2018)

\begin{tabular}{lllll}
\hline & $\begin{array}{l}\text { Monorail } \\
\text { Scenario }\end{array}$ & $\begin{array}{l}\text { Tram } \\
\text { Scenario }\end{array}$ & $\begin{array}{l}\text { Rapid Bus } \\
\text { Line Scenario }\end{array}$ & $\begin{array}{l}\text { Current Situation } \\
\text { Scenario }\end{array}$ \\
\hline $\begin{array}{l}\text { Energy Consumption } \\
\text { (Kcal) }\end{array}$ & 533.684 .180 & 503.353 .590 & 520.957 .830 & 495.602 .304 \\
\hline $\begin{array}{l}\text { Air Pollution (CO2) } \\
\text { Gr/Passenger-Km }\end{array}$ & 26.504 .856 & 25.047 .953 & 25.895 .436 & 24.612 .818 \\
\hline Noise (Db) & 83 & 83 & 83 & 88 \\
\hline Access Time (Min/Km) & $3 \mathrm{~min} 2 \mathrm{sec}$ & $1 \mathrm{~min} 53 \mathrm{sec}$ & $1 \mathrm{~min} 43 \mathrm{sec}$ & $4 \mathrm{~min} 8 \mathrm{sec}$ \\
\hline Travel Costs (TL) & 3,42 & 5,32 & 3,10 & 4,05 \\
\hline Investment Costs $\mathbf{( \$ ) ^ { 7 }}$ & $12.829 .885 \$$ & $21.511 .585 \$$ & $3.205 .527 \$$ & $0 \$$ \\
\hline
\end{tabular}

In the study, calculations are done via the conjoint model that has been formed based on the weight of criteria which resulted from the conjoint analysis. With the help of the conjoint analysis, the proposed scenarios for Rize transportation master plan are evaluated by the criteria set forth by the present study to produce a modern approach, and within the same modern framework a new scenario proposal is developed. It is necessary to know the criteria values of the conjoint model to be able to evaluate Rize transportation master plan scenarios in correlation with the conjoint model criteria shown in Table 7. In the model, among the scenario features and the criteria that signify the conjoint model variables, the transportation master plan data that are interrelated are used.

Table 7. RUAP Scenario Detail Features (KUTEM, 2018)

\begin{tabular}{ll}
\hline Transportation Master Plan Criteria & Conjoint Model Variables (Criteria) \\
\hline Energy Consumption (Kcal) & - \\
\hline Air Pollution (CO2) Gr/Passenger-Km & Emission \\
\hline Noise (Db) & Environmental Pollution \\
\hline Access Time (Min/Km) & Journey Time \\
\hline Travel Costs (Tl) & - \\
\hline Investment Costs (\$) & Investment Costs \\
\hline
\end{tabular}

7 Based on the dollar rate of 13.03. 2018 (1 $\$=3,87$ TL). 
In this regard, the Conjoint Model can be expressed as follows; DMFF: Constant + [1.Factor Level ${ }^{*}$ (1.Factor Correlation Coefficient (E.g.: Investment Cost) $)]+[2$. Factor Level *(2. Factor Correlation Coefficient (E.g.: Emission)) $]+[$ n. Factor Level *(n. Factor Correlation Coefficient]

Table 8 shows the Benefit value calculations obtained when the Conjoint Model is applied on Rize Transportation Master Plan scenario proposals. Here, the benefit value is produced by using the corresponding conjoint analysis values to the values in the transportation master plan scenarios. In this regard, while the tram scenario is paired with the coefficient which provides the minimum benefit since it has the highest investment cost, the access time variable of the direct bus line scenario, which has the shortest time of access, is paired with the coefficient that yields the maximum benefit.

Table 8 is completed by using the coefficients resulting from conjoint analysis and the coefficient of the relevant level for each criterion in the scenarios. After this stage, the scenario which gets the lowest score after the evaluation of negative criteria and calculation of the total value for each scenario by using the model in the scope of the conjoint analysis becomes the scenario which best satisfies the requirements.

According to what can be inferred from Table 8, the direct bus line scenario, which was proposed as part of Rize Transportation Master Plan, is the most feasible scenario considering the score it has.

Table 8. Calculation of Scenario Benefit Values

\begin{tabular}{lllllll}
\hline & & $\begin{array}{l}\text { Monorail } \\
\text { Scenario }\end{array}$ & $\begin{array}{l}\text { Tram } \\
\text { Scenario }\end{array}$ & $\begin{array}{l}\text { Rapid } \\
\text { Bus Line } \\
\text { Scenario }\end{array}$ & $\begin{array}{l}\text { Current } \\
\text { Situation } \\
\text { Scenario }\end{array}$ & $\begin{array}{l}\text { Corelation } \\
\text { Coefficient } \\
(\beta)\end{array}$ \\
\hline \multirow{4}{*}{$\begin{array}{l}\text { Benefit } \\
\text { Coefficients }\end{array}$} & $\begin{array}{l}\text { Investment } \\
\text { Cost }\end{array}$ & -4.474 & -6.711 & -2.237 & -2.237 & -2.237 \\
\cline { 2 - 7 } & $\begin{array}{l}\text { Air } \\
\text { Pollution }\end{array}$ & -1.357 & -1.357 & -2.714 & -1.357 & -1.357 \\
\cline { 2 - 7 } & Noise & -1.061 & -1.061 & -1.061 & -3.184 & -1.061 \\
\cline { 2 - 7 } & Access Time & -6.980 & -6.980 & -3.490 & -10.471 & -3.490 \\
\hline Constant & & 31 & 31 & 31 & 31 & - \\
\hline Total & & 68.335 & 73.339 & 52.992 & 77.767 & - \\
\hline
\end{tabular}

\section{Results and Recommandations}

Urban rail systems are means of transportation that produce economic, social and environmental benefits. However, it is observed that investment decisions about urban rail systems are mostly based on economic criteria, which 
brings along several limitations regarding the effectiveness of the investments. The present study puts forth investment criteria for urban rail systems that would satisfy the requirements of the modern world by using conjoint analysis. In the study, a new approach to feasibility to be considered by city governors and local authorities while making investment decisions for urban rail systems is developed. The study has shown that 'the number of passengers' criterion used in the current feasibility approach should not be the only effective criterion in investment decisions. When considered from a new and modern perspective, it can be suggested that the feasibility of urban rail systems should be shaped based on criteria which focus on shortening the travel time, promotes self-liquidating investments, ensures less spatial consumption, considers environmental and visual aesthetic qualities, contributes financially to its environs, and reduces private vehicle traffic.

As in other recent studies, conjoint analysis has used to find the best service option in this study. In accordance with the methodology of conjoint analysis, transportation, which is defined as a service in the literature, has been examined with the investment dimension. As a result of this examination, the scenario that provides the maximum benefit from the investment or service has been determined as in other studies which are concerns transportation. As can be seen from the results, it has been understood that taking social and environmental criteria into consideration will contribute to the development of medium and small-scale cities as in the feasibility approaches of other countries in the world.

\section{References}

AECOM. 2016. Bradley airport light rail feasibility study report. Bradley Development League. Connecticut. USA.

Akdemir, F., Ulvi, H., Aslınur, E., and Yilmaz, S., (2018). The Use of Multi-Criteria Assessment Techniques in Defining Sustainable Transport Systems for Different Sized Cities Ankara and Rize Example. Beyond All Limits (p.43-49). Ankara, Turkey

Aktaş, S., Akkuş, Ö. and Osmanoğlu, S. (2012). Çok düzeyli bağımlı değişken modellemesinde koşullu lojit ve konjoint analizlerinin performansları üzerine uygulamalı bir çalışma. İstanbul Ticaret Üniversitesi Fen Bilimleri Dergisi, 11(21), 25-40. 99

Alkan, S. N., and Yazıcıoğlu, F. (2017). City Center and Coastline Relations in Terms of Public Spaces through Black Sea Highway: Rize. Intercultural Understanding, 7, 7-11. Anonymous (2011). Mevcut demiryolu hattı fizibilite etüt raporu. Diyarbakır Büyükşehir Belediyesi, Diyarbakır.

Anonymous (2018). Rize Ulaşım Ana Planı. Gazi Üniversitesi KUTEM-Rize Belediyesi Ulaşım Hizmetleri Müdürlüğü. Rize 
Anonymous (2013a). Bölgesel Gelişme Ulusal Stratejisi 2014-2023. T.C. Kalkınma Bakanlığı, Ankara, Türkiye, 2013.

Anonymous (2013b). Onuncu Kalkınma Planı 2014-2018. T.C. Kalkınma Bakanlığı, Ankara, Türkiye, 2013.

Anonymous (2013c). Sakarya ulaşım ana planı (SUAP) ve öncelikli toplu taşıma sistemlerinin avan projeleri ile önfizibilite etütlerinin hazırlanması ön fizibilite etüt raporu 2013. Sakarya Büyükşehir Belediyesi, Sakarya

Anonymous (2008a). Mevcut tramvay hattını uzatılması avan proje, fizibilite etüdü ve tatbikat projesi fizibilite etüdü. Konya Büyükşehir Belediyesi Konya

Anonymous (2008b). 9 Haziran 2008 tarih ve 26901 sayıl Ulaşımda Enerji Verimliliğinin Artırılmasına İlişkin Usul ve Esaslar Hakkında Yönetmelik. Resmi Gazete.

Banister, D., and Thurstain-Goodwin, M. (2011). Quantification of the non-transport benefits resulting from rail investment. Journal of Transport Geography, 19(2), 212-223. doi.org/10.1016/j.jtrangeo.2010.05.001

Baştürk, G. (2014). Kent içi raylı toplu taşıma sistemleri incelemesi ve dünya örnekleri ile karşılaştırılması. Ulaştırma Haberleşme Bakanlığı Uzmanlık Tezi, 4-20.

Ben-Akiva, M., McFadden, D., and Train, K. (2019). Foundations of stated preference elicitation: Consumer behavior and choice-based conjoint analysis. Foundations and Trends in Econometrics, 10(1-2), 1-144. doi:10.1561/0800000036

Bilgiç, Ş. (2002). Türkiye'de ulaştırma yatırmmlarının değerlendirilmesi için çok ölçütlü bir yöntem geliştirilmesi. Doktora Tezi, Fen Bilimleri Enstitüsü. İstanbul Teknik Üniversitesi, İstanbul

Cankurt, M., Miran, B., and Gülsoylu, E. (2009). Çiftçilerin traktör tercihlerinin konjoint analizi ile belirlenmesi. Tarm Makinalarn Bilimi Dergisi, 5(1), 29-34. 98

Danielis, R., and Rotaris, L. (2002). Shippers' preferences for freight transport services: A conjoint analysis experiment for an Italian region. Transporti Europei 22. 27-35.

Deniz, M., Kazdal, K., and Topuz, M. (2020). Aile Sağlığı Merkezlerine Erişilebilirliğin CBS İle Analizine Bir Örnek: Rize Kenti. Atatürk Üniversitesi Sosyal Bilimler Enstitüsü Dergisi, 24 (3), 1407-1422.

Dimitriou, D. J. and Sartzetaki, M. F. (2017). Evaluation framework for investments in rail infrastructure projects. World Academy of Science, Engineering and Technology, International Journal of Social, Behavioral, Educational, Economic, Business and Industrial Engineering, 11(5), 1308-1312.

Eboli, L., and Mazzulla, G. (2010). How to capture the passengers' point of view on a transit service through rating and choice options. Transport Reviews, 30(4). 435-450. doi.org/10.1080/01441640903068441

Erdoğan, H. T. (2016). Ulaşım hizmetlerinin ekonomik kalkınma üzerine etkisi. İstanbul Gelişim Üniversitesi Sosyal Bilimler Dergisi, 3(1), 187-215. doi:10.17336/igusbd.05060

Frehe, V. (2015). Can target costing be applied in green logistics? -evidence from a conjoint analysis. Paper Presented in ECIS 2015, Münster. Germany. ISBN 978-3-00-050284-2. 
Gündüz, A. Y., Mehmet, K., and Aydemir, C., (2011). Kentiçi ulaşımında karayolu ulaşımına alternatif sistem: Raylı ulaşım sistemi. Akademik Yaklaşımlar Dergisi, 2(1).134-151,

Gürbüz, H., and Kaygısız, Z. (2004). Konjoint analizi ve ulaşım sektör pazarı üzerine bir çalışma. Süleyman Demirel Üniversitesi İktisadi ve İdari Bilimler Fakültesi Dergisi. 9(1). 139-148.

Gökyurt, F., Kındap, A., and Sarı, V. İ. (2015). Türkiye için yeni bir şehir tanımı gerekli mi?, Çă̆daş Yerel Yönetimler Dergisi, 24(1), 1-32.

Görer Tamer N., S. Atik, V. Özbilen, S. Özden and K. Seyrek., (2007). Bölge ve Kent Planlama ile Su Tüketim İlişkisi: Dünya ve Ankara Örnekleri. Planlama, 3-4, 9-22, Ankara, Türkiye, ISSN: 1300-7319.

Haghshenas, H. and Vaziri M. (2012). Urban sustainable transportation indicators for global comparison. Ecological Indicators, 15(1), 115-121.

Jayaraman, K., Suan, J. C. S., and Lin, S. K. (2011). Robust models for the utilization of public bus transport services in Malaysia. African Journal of Business Management. 5(26). 10586-10600. doi: 10.5897/AJBM11.510

Kellog S. and Pettigrew S. (2013). Şehirdekiler İçin Sürdürülebilir Yaşam Rehberi. İstanbul. Sineksekiz Yayınevi.

Kılınçarslan, T. (Der.). (2012). Kentsel Ulaşım: Ulaşım Sistemi-Toplu Taşım-Planlama-Politikalar. İstanbul: Ninova Yayınları.

Kılıçaslan, H. (2015). Expanding the rail transport services of municipalities: The case of Bursa metropolitan municipality. Yönetim ve Ekonomi, 22(2), 451.

Kofteci, S., Ergun, M., and Ay, S. (2010). Modeling freight transportation preferences: Conjoint analysis for Turkish Region. Scientific Research and Essays, 5(15). 2016-2021.

Kim, G., and Han, S. (2011). Comparative analysis of transportation sustainability in OECD countries. Journal of the Eastern Asia Society for Transportation Studies, 9, 82-97.

Murteza, M. (2010). Raylı sistem yatırımlar fizibilite etüdleri ve yapım yöntemleri. $\mathrm{PhD}$ Thesis, Bahçeşehir Üniversitesi Fen Bilimleri Enstitüsü. İstanbul, 30-39.

Newman, P. (2012). Why do we need a good public transport system. Research Paper, Curtin University Sustainability Policy (CUSP) Institute.

Öğüt, K. S., and Evren, G. (2006). Topics to be aware of the necessity and practice of urban rail systems in Turkey. International Railway Symposium, Turkey, 1-10.

Russo, F. and Comi, A., (2012). City characteristics and urban goods movements: A way to environmental transportation system in a sustainable city. Procedia-Social and Behavioral Sciences, 39, 61-73. doi.org/10.1016/j.sbspro.2012.03.091

Sümer, G. Ç. (2014). Rize'de Kentleşme Süreci. Ekonomik ve Sosyal Araştırmalar Dergisi, 10(10), 163-183.

Spiekermann, K., and Wegener, M. (2006). Accessibility and spatial development in Europe. Scienze Regionali, 5(2), 15-46.

Şahin, S. Z. (2012). The relationship between urban planning process and urban infrastructure investments: Ankara case. Chamber of Civil Engineers. Presented at 6th Urban Infrastructure Symposium, Antalya. 
Turanl1, M., Cengiz, D. T.and Mert, I. (2013). Konjoint analizi ile gazete tercihlerini etkileyen faktörlerin belirlenmesi. Ekonometri ve İstatistik, (19), 1-26.

Tsimplokoukou, K., Sfakianaki, E., and Metaxas, G. (2012). A feasibility study approach for underground railways-a case study: Line 4 of Athens metro. Global Journal of Engineering Education, 14(1). 91-98.

Van der Loop, J. T. A. and de Jong, G. C. (1997). What is the best public transport system? An instrument to compare urban public transport systems using transportational, environmental and social criteria. WIT Transactions on The Built Environment, 30. 205213.

Wardman, M. (2014). Valuing convenience in public transport: Roundtable summary and conclusions. International Transport Forum Discussion Paper.

Withanaarachchi, J. and Setunge, S. (2014). Decision making on transport network planning and the impact on community, economy and the environment. Procedia Economics and Finance, 18, 882-891. doi:10.1016/S2212-5671(14)01014-4.

Wooliscroft, B., and Ganglmair-Wooliscroft, A. (2014). Improving conditions for potential New Zealand cyclists: An application of conjoint analysis. Transportation research part A: policy and practice. 69. 11-19. doi.org/10.1016/j.tra.2014.08.005.

Yavuz, S., and Çemrek, F. (2013.) Konjoint Analizi İle Sağlık Çalışanlarının Konut Tercihlerinin Belirlenmesi. Atatürk Üniversitesi Sosyal Bilimler Enstitüsü Dergisi, 17(2), 379-396. 97

Zak, J. (2011). The methodology of multiple criteria decision making/aiding in public transportation. Journal of Advanced Transportation, 45(1), 1-20. 